удК $336.221: 336.14$

А. П. Киреенко

Байкальский государственный университет, г. Иркутск, Российская Федерация

Е. Н. Орлова

Байкальский государственный университет, г. Иркутск, Российская Федерация

\title{
ПОВЫШЕНИЕ ДОХОДНОГО ПОТЕНЦИАЛА МЕСТНЫХ БЮДЖЕТОВ НА ОСНОВЕ ЗАКРЕПЛЕНИЯ ДОПОЛНИТЕЛЬНЫХ НАЛОГОВЫХ ДОХОДОВ
}

\begin{abstract}
АНнОТАЦИЯ. Исследуется возможность повышения налоговых доходов местных бюджетов на основе установления нормативов отчисления от налога на имущество организаций. Анализируется распределение налога на имущество по городским округам и муниципальным районам Иркутской области по данным налоговой статистики и данным о распределении кадастровой стоимости имущества. Изучены достоинства и недостатки различных налогов с позиции их распределения на муниципальный уровень. Делается вывод, что налог на имущество организаций отвечает необходимым для передачи на местный уровень требованиям. Доказано, что распределение налоговой базы по налогу на имущество по данным налоговой отчетности и государственной статистики не отражает реального распределения имущества по территории региона. Для прогнозирования последствий установления предложенного норматива предлагается корректировать сведения о распределении имущества по территории региона по данным о кадастровой оценке объектов недвижимости. ключЕВыЕ словА. Налоги; местные бюджеты; доходы местных бюджетов; налог на имущество организаций; нормативы отчислений.

ИНФОРМАЦИЯ О СТАТЬЕ. Дата поступления 31 октября 2017 г.; дата принятия к печати 19 декабря 2017 г.; дата онлайн-размещения 29 декабря 2017 г.

ФИНАНСИРОВАНИЕ. Исследование выполнено при финансовой поддержке гранта РФФИ № 17-22-01002/17 «Методология изучения уклонения от уплаты налогов путем проведения налоговых экспериментов в системе обеспечения экономической безопасности России и Беларуси».
\end{abstract}

A. P. Kireyenko Baikal State University, Irkutsk, Russian Federation

Ye. N. Orlova Baikal State University, Irkutsk, Russian Federation

\section{THE INCREASE OF THE REVENUE POTENTIAL OF LOCAL BUDGETS BASED ON FIXING ADDITIONAL TAX REVENUES}

\begin{abstract}
The article investigates the possibility of increasing the tax revenues of local budgets based on establishment of standards for reductions from the property tax of institutions. The distribution of the property tax in urban districts and municipal districts of Irkutsk Oblast is analyzed according to the data of tax statistics and data on distribution of the cadastral value of property. The article studies the advantages and disadvantages of various taxes from the perspective of their distribution to the municipal level. It is concluded that the property tax of institutions meets the requirements for the transmission to the local level. The article proves that distribution of the tax base for property tax, according to the data of tax reports and government statistics, does not reflect the real property distribution throughout the territory of the region. To predict the consequences of establishing the suggested standard, it is proposed to correct information on the property distribution throughout the territory of the region from the data on the cadastral valuation of real estate. KEYWORDS. Taxes; local budget revenues; property tax; distribution standards.
\end{abstract}

(C) А. П. Киреенко, Е. Н. Орлова, 2017

\section{Baikal Research Journal}


ARTICLE INFO. Received October 31, 2017; accepted December 19, 2017; available online December 29, 2017.

ACKNOWLEDGEMENTS. The study was carried out with the financial support of the RFBR grant No. 17-22-01002 / 17 «Methodology for the study of tax evasion by conducting tax experiments in the system of ensuring economic security of Russia and Belarus».

Ограниченность собственных доходов местных бюджетов в Российской Федерации имеет свою историю, которая во многом определяет истоки сегодняшней проблемы. До Великой Октябрьской социалистической революции в России не было самостоятельных местных бюджетов. Большая часть волостных и мирских сборов шла на общегосударственные нужды. Сразу же после революции наступил короткий период полной самостоятельности местных бюджетов и чрезмерной налоговой инициативы мест. Налоговая реформа начала 1930-х гг. резко разграничила государственные и местные доходы и изъяла у местных бюджетов ведущие источники доходов. Местные Советы потеряли заинтересованность в изыскании дополнительных доходов и своевременном их поступлении. Прямые дотации, до реформы, применявшиеся лишь в крайних случаях, стали для многих местных бюджетов основным источником существования. В условиях кризиса местные бюджеты попадают в своеобразные «ножницы» когда доходы сокращаются, а расходы растут в связи с ростом социальных расходов.

Доходы местных бюджетов зависят не только от того, какие права им выделит федерация, но и какими доходами поделится с ними субъект. Субъекты, сталкиваясь с сокращением собственной доходной базы, в свою очередь, сокращают доходы, передаваемые в местные бюджеты.

Научной разработке теоретических основ децентрализации доходных и расходных полномочий, сбалансированности бюджетов посвящены работы таких зарубежных ученых, как У. Оутс [1; 2], Р. Берд [3], Р. Масгрейв [4], Г. Бреннан и Дж. Бьюкенен [5]. В отечественной научной литературе проблемам повышения финансовой самостоятельности регионов и муниципальных образований посвящено большое число исследований, в рамках которых в той или иной мере внимание уделяется ее методическим и практическим аспектам [6; 7; 8; 9]. Работы, посвященные оценке последствий закрепления дополнительных налоговых доходов за местными бюджетами на региональном уровне, встречаются в экономической литературе реже $[10 ; 11$, с. $124 ; 12 ; 13$, с. 244-246; 14]. Установление регионом нормативов отчислений в местные бюджеты возможно от федеральных, региональных налогов и сборов, являющихся источником формирования бюджетов субъектов Российской Федерации. В табл. 1 представлены данные о распределении налоговых доходов в соответствии с бюджетным законодательством.

В табл. 1 приведены также недостатки установления отчислений от поступающих в региональные бюджеты налогов. Теоретически, налоги, которые могут быть переданы на местный уровень, должны отвечать ряду принципиальных требований:

- справедливое распределение базы налога по всей территории;

- сбор налога не должен требовать крупных затрат на обслуживание в небольших масштабах, от налога должно быть сложно уклониться, чтобы не требовались дополнительные средства на налоговый контроль;

- налоги должны обеспечивать высокий и стабильный доход, так как на местном уровне имеется незначительное количество источников налоговых доходов;

- налоговая база должна находиться в пределах юрисдикции налоговых органов соответствующего уровня для исключения или минимизации «миграции» налоговой базы по налогу;

- налоги не должны порождать территориальные диспропорций в распределении доходов и являться стимулом к миграции населения.

\section{Baikal Research Journal}

электронный научный журнал Байкальского государственного университета 
Налоги и сборы, подлежащие зачислению в бюджеты субъектов РФ и лестные бюджеты в 2017 2., полнолочия по установлению норлативов отчислений от которых илеются у региональных органов власти

\begin{tabular}{|c|c|c|c|}
\hline \multirow[t]{2}{*}{ Налог } & \multicolumn{2}{|c|}{$\begin{array}{c}\text { Подлежит зачислению в } \\
\text { соответствии с Бюджет- } \\
\text { ным кодексом, \% } \\
\end{array}$} & \multirow{2}{*}{$\begin{array}{c}\text { Недостатки установления отчислений } \\
\text { в местные бюджеты }\end{array}$} \\
\hline & $\begin{array}{c}\text { в бюджеты } \\
\text { субъектов РФ }\end{array}$ & $\begin{array}{c}\text { в местные } \\
\text { бюджеты } \\
\end{array}$ & \\
\hline Транспортный налог & 100 & - & $\begin{array}{l}\text { - минимальное количество незарегистриро- } \\
\text { ванных объектов и, следовательно, отсут- } \\
\text { ствие фактора стимулирования к расшире- } \\
\text { нию налоговой базы; } \\
\text { - возможность «миграции» налоговой базы } \\
\text { (в частности в связи со сменой юридическо- } \\
\text { го адреса организаций и перерегистрацией } \\
\text { транспортных средств); } \\
\text { - незначительная доля в доходах региональ- } \\
\text { ного бюджета (как правило, менее } 2 \text { \%), } \\
\text { темпов роста, как следствие несуществен- } \\
\text { ная роль в повышении сбалансированно- } \\
\text { сти местных бюджетов в случае передачи } \\
\text { прироста поступлений }\end{array}$ \\
\hline $\begin{array}{l}\text { Налог на прибыль по } \\
\text { ставке, установленной } \\
\text { для зачисления в бюд- } \\
\text { жет субъекта }\end{array}$ & 100 & - & $\begin{array}{l}\text { - зависимость от экономической ситуации, } \\
\text { финансового состояния налогоплательщи- } \\
\text { ков - организаций; } \\
\text { - влияние организационной структуры ор- } \\
\text { ганизаций (возможность перераспределения } \\
\text { прибыли между обособленными подразделе- } \\
\text { ниями не в зависимости от фактических ре- } \\
\text { зультатов их деятельности, а от показателей } \\
\text { численности (фонда оплаты труда работни- } \\
\text { ков) и остаточной стоимости имущества) }\end{array}$ \\
\hline Акцизы & $40-100^{*}$ & - & \multirow{2}{*}{$\begin{array}{l}\text { - неравномерное размещение налоговой } \\
\text { базы по территории области: по месту } \\
\text { нахождения производителей подакцизных } \\
\text { товаров и участков недр }\end{array}$} \\
\hline НДПИ & $60-100^{* * *}$ & - & \\
\hline $\begin{array}{l}\text { Сбор за пользование } \\
\text { объектами водных био- } \\
\text { логических ресурсов }\end{array}$ & 80 & - & \multirow[t]{2}{*}{$\begin{array}{l}\text { - носят разовый характер; } \\
\text { - незначительная доля в доходах регио- } \\
\text { нального бюджета }\end{array}$} \\
\hline $\begin{array}{l}\text { Сбор за пользование объ- } \\
\text { ектами животного мира }\end{array}$ & 100 & - & \\
\hline $\begin{array}{l}\text { Налог на доходы физи- } \\
\text { ческих лиц }\end{array}$ & 85 & $15^{* * * *}$ & \multirow{2}{*}{$\begin{array}{l}\text { - возможность «миграции» налоговой базы; } \\
\text { - уплата не по месту жительства платель- } \\
\text { щика, а по месту регистрации работодателя } \\
\text { - налогового агента }\end{array}$} \\
\hline НДФЛ в виде ФАП & 100 & - & \\
\hline $\begin{array}{l}\text { Налог на имущество } \\
\text { организаций }\end{array}$ & 100 & - & \\
\hline $\begin{array}{l}\text { Налог, взимаемый в свя- } \\
\text { зи с применением УСН }\end{array}$ & 100 & - & \\
\hline
\end{tabular}

Всем указанным требованиям отвечает очень незначительное число налогов, поэтому основными доходными источниками бюджетов местного уровня являются налог на доходы физических лиц, налог, взимаемый в связи с применением УСН, налог на имущество.

\section{Baikal Research Journal}


При выборе налога в целях установления нормативов отчислений в местные бюджеты необходимо также чтобы налог отвечал следующим критериям:

- низкая зависимость от колебаний цен и финансового состояния налогоплательщиков;

- наличие заинтересованности органов власти муниципальных образований в увеличении налоговой базы и росте поступлений по налогу.

Остановимся более подробно на перспективах передачи на местный уровень части доходов от налога на имущество организаций. Налог на имущество организаций является прямым, региональным налогов и взимается на основании гл. 30 Налогового кодекса РФ. Каждый субъект РФ принимает на своей территории закон субъекта РФ о налоге на имущество организаций, где имеет право указать дифференциацию налоговых ставок, прописать льготные категории налогоплательщиков, установить сроки уплаты и налоговую базу - кадастровую стоимость для отдельных объектов. Особое внимание хотелось бы уделить плюсам данного налога, к которым в частности относится [15, с. 253]:

- стабильность налоговых поступлений;

- низкая мобильность налоговой базы;

- отсутствие зависимости от финансового состояния налогоплательщика и макроэкономической ситуации;

- в виду близости к объектам возможность осуществления со стороны местных органов власти мероприятий по вовлечению в экономический оборот бесхозяйного и сокрытого от учета недвижимого имущества и увеличения на этой основе доходного потенциала местных бюджетов.

Все это способствует тому, что в ряде регионов Российской Федерации налог на имущество отнесен к числу налогов, которые частично передаются на местный уровень - муниципальным районам и городским округам (рис.) ${ }^{1}$.

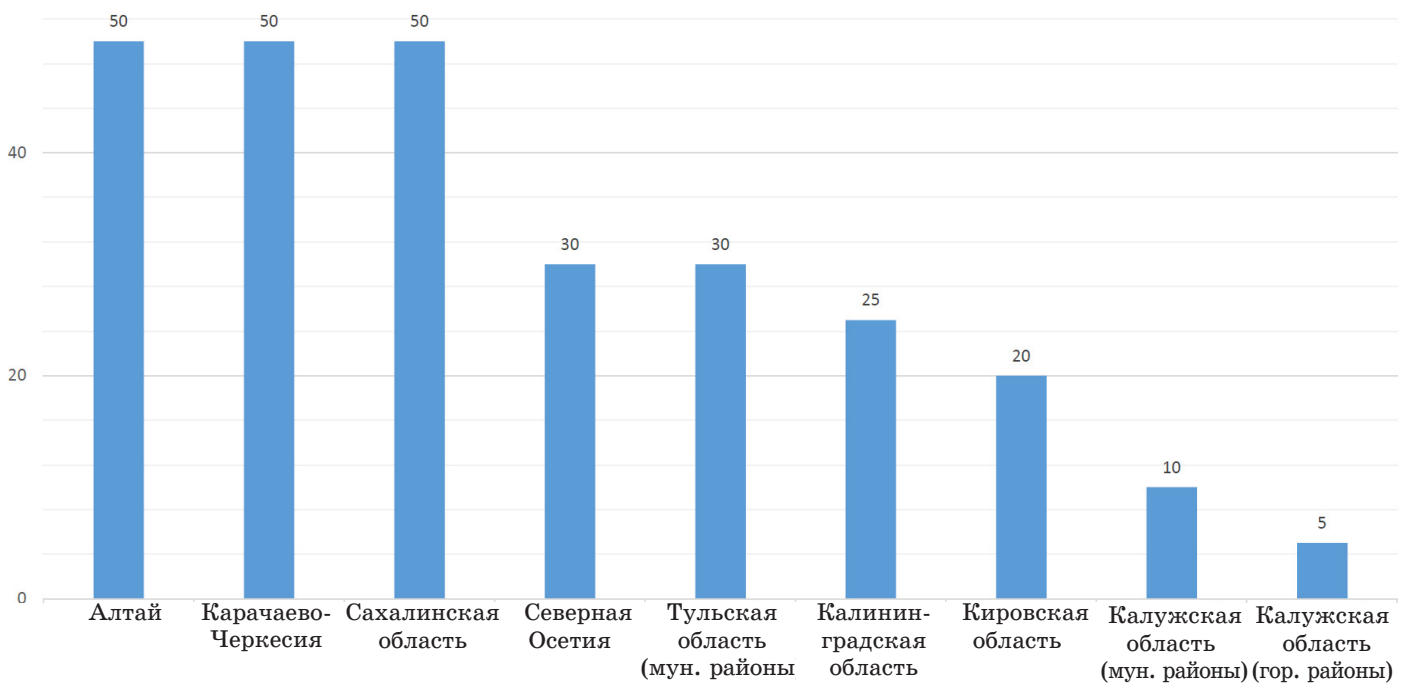

Норлативы отчислений от налога на имущество организаций в местные бюджеты в отдельных регионах Российской Федерации

\footnotetext{
${ }^{1}$ Необходимо отметить, что в соответствии с Федеральным законом от 25.09.1997 № 126-ФЗ «О финансовых основах местного самоуправления в Российской Федерации» (утратил силу с 01.01.2009г.) к собственным доходам местных бюджетов относилось не менее 50 \% налога на имущество предприятий (организаций).
}

\section{Baikal Research Journal}


Одним из условий передачи доходов от налога на местный уровень, как уже отмечалось, является равномерность распределения налоговой базы. Анализ распределения налога на имущество по городским округам и муниципальным районам на примере Иркутской области показал, что более 50 \% налогоплательщиков и около 60 \% исчисленного налога приходится на областной центр - г. Иркутск, далее следует 2 крупных муниципалитета - г. Братск и Ангарское муниципальное образование.

Необходимо отметить, что пропорции распределения налога по территории региона во многом определяются особенностями уплаты данного налога в случае рассредоточения имущества по территории региона или при наличии обособленных подразделений у крупных налогоплательщиков-организаций, местом регистрации которых, как правило, выступают крупные города:

- при уплате налога по месту нахождения обособленных подразделений основополагающим является наличие отдельного баланса: при наличии отдельного баланса налог уплачивается за движимое и недвижимое имущество, находящееся на отдельном балансе подразделения в бюджет по месту его нахождения, при отсутствии отдельного баланса уплата производится только за недвижимое имущество, соответственно движимое подлежит налогообложению по месту нахождения организации ${ }^{2}$;

- при наличии имущества, находящегося в разных муниципальных образованиях одного субъекта РФ, организации имеют право подавать одну декларацию и, соответственно, уплачивать налог только по месту своего нахождения, если законодательством субъекта РФ предусмотрено зачисление налога в региональный бюджет без направления в бюджеты муниципальных образованийㄱ․ В этом случае, все имущество, рассредоточенное по территории региона может отражаться в декларации как поставленное на учет в областном центре.

Таким образом, распределение налоговой базы по налогу на имущество по данным налоговой отчетности не отражает ее реального распределения по территории региона. Более того, информация, предоставляемая организациями в органы государственной статистики, соответствует налоговой отчетности и также не отражает реального распределения имущества по территории области. Соответственно статистическая информация о распределении стоимости основных фондов также не даст объективной картины.

Для того, чтобы скорректировать сведения о распределении имущества по территории региона целесообразно использовать информацию о кадастровой оценке объектов недвижимости. Отчеты о результатах ее проведения размещаются на сайте Федеральной службы государственной регистрации, кадастра и картографии. Для этого из общей информационной базы о кадастровой стоимости недвижимости на территории региона необходимо выделить данные об объектах недвижимости, принадлежащих юридическим лицам. Исходя из существующей классификации юридическим лицам принадлежат нежилые объекты, входящие в 5-13 группы ${ }^{4}$. Группировка входящих в указанные группы объектов позволя-

${ }^{2}$ Налоговый кодекс Российской Федерации. Ч. 2. Ст. 384 [Электронный ресурс] : федер. закон от 5 авг. 2000 г. № 117 : (ред. от 30 окт. 2017) // СПС «КонсультантПлюс».

${ }^{3}$ Об утверждении форм и форматов представления в электронном виде налоговой декларации и налогового расчета по авансовому платежу по налогу на имущество организаций и порядков их заполнения [Электронный ресурс] : приказ ФНС России от 24 нояб. 2011 № МMB-7-11/895 : (ред. от 05 нояб. 2013) // СПС «КонсультантПлюс».

${ }^{4} 5$ группа - объекты торговли, общественного питания, бытового обслуживания, сервиса, отдыха и развлечений, включая объекты многофункционального назначения; 6 группа - объекты, предназначенные для временного проживания гостиничного типа; 7 группа - объекты офисно-делового назначения; 8 группа - объекты санаторно-курортного назначения; 9 группа - объекты производственного назначения; 10 группа - объекты социальной инфраструктуры; 11 группа - объекты портов, вокзалов, станций; 12 группа - объекты иного назначения; 13 группа - сооружения.

\section{Baikal Research Journal}

электронный научный журнал Байкальского государственного университета 
ет исчислить кадастровую стоимость нежилых объектов недвижимости, а также сгруппировать площадь данных объектов.

На основе соотношения кадастровой стоимости имущества и площади можно рассчитать средние значения кадастровой стоимости за 1 м $^{2}$ по каждой группе (за исключением 13-ой группы). Затем полученный показатель средней кадастровой стоимости применить к площади помещений соответствующей группы по каждому муниципальному образованию, что обеспечит выравнивание оценки кадастровой стоимости. Стоимость сооружений, учитываемых в 13-ой группе, необходимо принять в расчет по утвержденной оценке без корректировки на среднюю стоимость ввиду отсутствия по данной группе информации о площади сооружений. Далее кадастровая стоимость с учетом корректировки на среднюю стоимость по 5-12 группам и по 13-ой группе суммируется, и определяется удельный вес стоимости имущества организаций каждого муниципального образования в общей кадастровой стоимости имущества юридических лиц по региону. Указанное значение удельного веса можно применить в фактической сумме налоговой базы по налогу на имущество организаций в субъекте РФ.

Описанная методика была апробирована при оценке распределения недвижимого имущества организаций по муниципальным образованиям Иркутской области. В результате перераспределения наиболее существенное уменьшение налоговой базы наблюдается именно в крупных городах и, особенно, в областном центре. Выиграет от перераспределения налоговой базы 36 муниципальных образований из 42 (рис. 2).

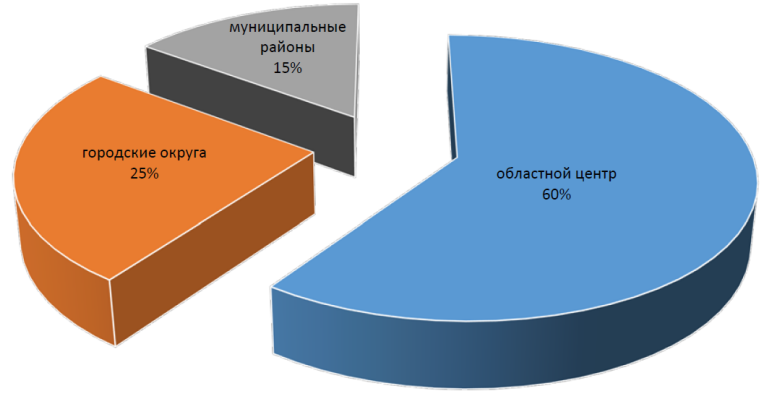

Налоговая база фактическая (по отчету 5-ниО)

- областной центр " городские округа "муниципальные районы

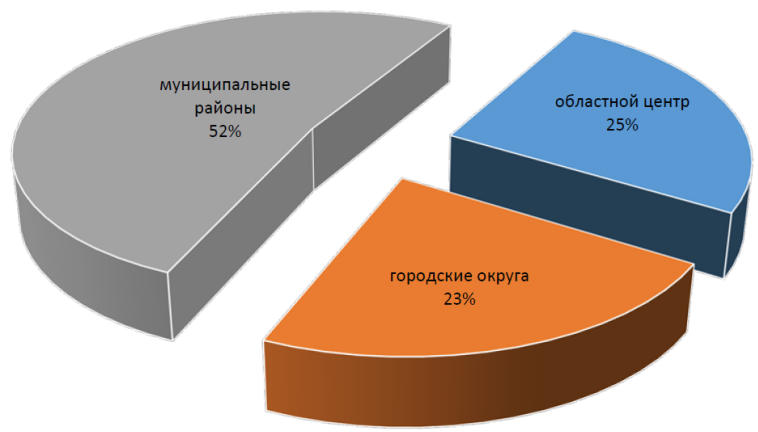

Налоговая база с учетом перерапределения по МO

- областной центр " городские округа " муниципальные районы

Рис. 2. Распределение налоговой базы организаций на основе данных о кадастровой стоилости, \%

\section{Baikal Research Journal}


Полученные оценки перераспределения налоговой базы позволяют произвести ее дальнейшую корректировку на прогноз роста налоговой базы, рассчитать сумму налога и оценить перспективы роста налоговых доходов муниципалитетов при условии передачи части налога на местный уровень. На примере Иркутской области установление норматива отчислений на уровне $10 \%$ приведет к зачислению в местные бюджеты суммы, сопоставимой с суммой дотаций. Однако, ввиду его перераспределения, в полном размере поступление налога будет покрывать дотации в 6 муниципальных образованиях, в одном - на $70 \%$, на 25-35\% - в 7 муниципальных образованиях. При условии установления норматива отчислений $20 \%$ в полном размере поступление налога будет покрывать дотации в 7 муниципальных образованиях, еще в 7 муниципальных образованиях — на 50-70 \%, в 6 муниципальных районах — на 35-49\%. При этом средства, высвободившиеся в результате отмены дотаций повысившим свою бюджетную обеспеченность за счет отчислений от налога на имущество муниципальным образованиям, могут быть направлены на выравнивание обеспеченности остальных муниципалитетов.

Еще одним преимуществом установления норматива отчислений именно по налогу на имущество является более умеренное перераспределение, чем при передаче на муниципальный уровень других налогов, распределение которых уже принято или рассматривается как возможное (табл. 2).

Оценка дополнительных доходов бюджетов (выпадающих доходов областного бюджета) от реализации предложений по изменению нормативов отчислений на примере городских округов Иркутской области, млн р.

\begin{tabular}{|c|c|c|c|c|}
\hline $\begin{array}{c}\text { Муниципальное } \\
\text { образование }\end{array}$ & $\begin{array}{c}\text { Дополнитель- } \\
\text { ные доходы } \\
\text { от передачи } \\
3 \% \\
\text { от НДФЛ }\end{array}$ & $\begin{array}{c}\text { Дополнитель- } \\
\text { ные доходы от } \\
\text { передачи } 30 \% \\
\text { налога } \\
\text { по упрощенной } \\
\text { системе }\end{array}$ & $\begin{array}{c}\text { Дополнительные } \\
\text { доходы от налога } \\
\text { на имущества орга- } \\
\text { низаций } \\
\text { по нормативу } \\
\text { отчислений } 10 \%\end{array}$ & $\begin{array}{c}\text { Дополнительные } \\
\text { доходы от нало- } \\
\text { га на имущества } \\
\text { организаций } \\
\text { по нормативу } \\
\text { отчислений } 20 \text { \% }\end{array}$ \\
\hline $\begin{array}{l}\text { Всего перераспре- } \\
\text { деление доходов в } \\
\text { пользу городских } \\
\text { округов, } \\
\text { в том числе: }\end{array}$ & 879,7 & 1008,1 & 994,4 & 1988,8 \\
\hline областной центр & 507 & 645,9 & 401 & 802 \\
\hline $\begin{array}{l}\text { другие городские } \\
\text { округа }\end{array}$ & 372,7 & 362,2 & 593,4 & 1186,8 \\
\hline
\end{tabular}

Следует отметить, что на случай возникновения в бюджетах муниципальных образований чрезмерных доходов в Федеральном законе от 06.10.2003 № 131-Ф3 «Об общих принципах организации местного самоуправления в Российской Федерации» есть п. 4 ст. 61, который определяет, что сложившаяся «чрезмерность» в качестве «отрицательного» трансферта может быть изъята для аккумулирования в региональном фонде финансовой поддержки (у субъекта РФ) для последующего перераспределения в виде дотаций нуждающимся муниципальным образованиям. В Бюджетном кодексе РФ (ст. 142.2) отрицательные трансферты именуются субсидиями бюджету субъекта РФ из местных бюджетов и аккумулируются в региональном фонде финансовой поддержки муниципальных районов (городских округов) либо в аналогичном фонде поселений.

\section{Baikal Research Journal}




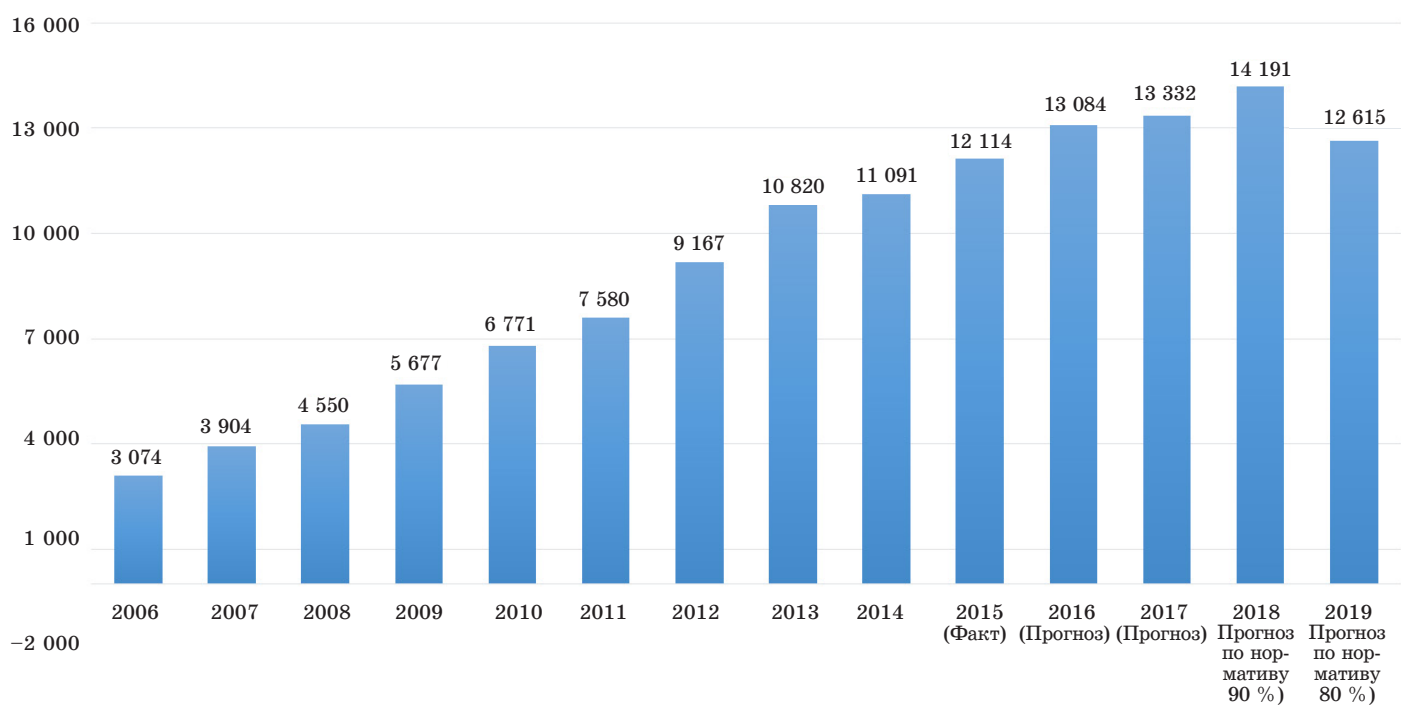

Рис. 3. Прогноз начисления налога на илущество организаций на территории Иркутской области, млн р.

Необходимо также отметить, что зачисление налога на имущество в местные бюджеты по нормативу 10 \%, как показано на рис. 3 , не приведет к снижению доходов областного бюджета. Это обусловлено тем, что переход на кадастровую стоимость для отдельных объектов и реализация даже на минимальном уровне мероприятий по вовлечению в экономический оборот бесхозяйного и сокрытого от учета недвижимого имущества будет способствовать повышению налога, прирост которого компенсирует передачу части налога в местные бюджеты. При установлении норматива отчислений в местные бюджеты в размере $20 \%$ сумма налога в областной бюджет останется на уровне 2015-2016 гг.

Таким образом, налог на имущество организаций в качестве источника формирования доходов местных бюджетов отвечает требованиям стабильности, независимости от колебаний цен и финансового состояния налогоплательщиков, равномерности распределения по территории региона и невозможности миграции налоговой базы (в части недвижимого имущества). Кроме того, ввиду близости к объектам налогообложения установление нормативов отчислений по данному налогу повышает заинтересованность органов власти муниципальных образований в увеличении налоговой базы и росте поступлений по налогу. При этом его частичное закрепление за местными бюджетами обеспечивает более справедливое по сравнению другими налогами перераспределение налоговых поступлений между крупными городами и муниципальными районами, сглаживая диспропорции в пользу последних. Вместе с тем ввиду недавнего введения налогообложения по кадастровой стоимости объектов, неравномерного изменения по этой причине налоговой базы, как показывает опыт отдельных регионов, а также изменений налогового законодательства в части установления льгот и пониженных ставок в 2017-2018 гг., необходима детальная проработка и дальнейшая оценка последствий изменения распределения налога.

\section{Список использованной литературы}

1. Oates W. E. On the Theory and Practice of Fiscal Decentralization [Electronic resource] / W. E. Oates // IFIR Working Paper Series. - 2006. - № 5. - Mode of access:

\section{Baikal Research Journal}


https://www.researchgate.net/publication/5110773_On_the_Theory_and_Practice_of_Fiscal_ Decentralization.

2. Oates W. E. Toward A Second-Generation Theory of Fiscal Federalism [Electronic resource] // International Tax and Public Finance. - 2005. - Vol. 12, iss. 4. - P. 349-373. Mode of access: https://link.springer.com/article/10.1007\% 2Fs10797-005-1619-9.

3. Bird R. M. Subnational Taxation in Developing Countries: a Review of the Literature [Electronic resource] / R. M. Bird // Policy Research Working Paper. - 2010. — October. P. 6. - Mode of access: https://openknowledge.worldbank.org/handle/10986/3933.

4. Масгрейв Р. А. Государственные финансы: теория и практика : пер. с англ. / Р. А. Масгрейв, П. Б. Масгрейв. - М. : Бизнес Атлас, 2009. - 716 с.

5. Brennan G. The power to tax: Analytic foundations of a fiscal constitution / G. Brennan, J. M. Buchanan. - Cambridge : Cambridge University Press, 1980. - 231 p.

6. Ермакова Е. А. Проблемы и возможности увеличения доходов местных бюджетов: налоговый аспект / Е. А. Ермакова // Наука и общество. - 2012. — № 4. - С. 27-31.

7. Киреенко А. П. Проявления региональной налоговой политики в условиях российского бюджетного федерализма / А. П. Киреенко, Е. Н. Орлова // Регион: экономика и социология. - 2014. - № 1 (81). - С. 193-217.

8. Киреенко А. П. Налоговые аспекты межбюджетных отношений Электронный ресурс] / А. П. Киреенко, Т. В. Сорокина // Baikal Research Journal. — 2011. — № 5. — C. 2. - Режим доступа: http://brj-bguep.ru/reader/article.aspx?id=9671.

9. Пинская М. Р. Поземельное налогообложение и резервы роста налоговых доходов местных бюджетов / М. Р. Пинская // Налоги и финансы. - 2014. - № 2. - С. 26-32.

10. Истомина Н. А. Региональная практика установления дифференцированных нормативов отчислений по налогам для бюджетов муниципальных образований / Н. А. Истомина // Известия Уральского государственного экономического университета. — 2011. № 6 (38). - С. 28-40.

11. Колодина Е. А. Бюджетный федерализм как основа региональной экономической политики в современной России / Е. А. Колодина // Известия Иркутской государственной экономической академии (БГУЭП). — 2011. — № 6. - С. 121-124.

12. Покровская Н. В. Роль налоговых трансфертов в формировании местных бюджетов в Российской Федерации [Электронный ресурс] / Н. В. Покровская // Baikal Research Journal. - 2015. - T. 6, № 3. - C. 8. — DOI: 10.17150/2072-0904.2015.6(3).8. — Режим доступа: http://brj-bguep.ru/reader/article.aspx?id=20121.

13. Сумская Т. В. Основные направления укрепления местных бюджетов / Т. В. Сумская // Регион: экономика и социология. - 2010. - № 1. - С. 235-254.

14. Ivanova O. Yu. Tax aspects of financial resources decentralization / O. Yu. Ivanova, O. Yu. Polyakova // Journal of Tax Reform. - 2016. - T. 2, № 1. - C. 25-42. - DOI: 10.15826/jtr.2016.2.1.015.

15. Хон С. С. Системный подход к налогообложению недвижимого имущества организаций / С. С. Хон, И. А. Майбуров // Инновационное развитие экономики. - 2016. № 3-1 (33). - С. 253-258.

\section{References}

1. Oates W. E. On the Theory and Practice of Fiscal Decentralization. IFIR Working Paper Series, 2006, no. 5. Available at: https://www.researchgate.net/publication/5110773_ On_the_Theory_and_Practice_of_Fiscal_Decentralization.

2. Oates W. E. Toward A Second-Generation Theory of Fiscal Federalism. International Tax and Public Finance, 2005, vol. 12, iss. 4, pp. 349-373. Available at: https://link.springer.com/article/10.1007\% 2Fs10797-005-1619-9.

3. Bird R. M. Subnational Taxation in Developing Countries: a Review of the Literature. Policy Research Working Paper, 2010, October, pp. 6. Available at: https://openknowledge. worldbank.org/handle/10986/3933.

4. Musgrave R. A., Musgrave P. B. Public Finance in Theory and Practice. $5^{\text {th }}$ ed. New York, 1973. (Russ. ed.: Masgreiv R. A., Masgreiv P. B. Gosudarstvennye finansy: teoriya $i$ praktika. Moscow, Biznes Atlas Publ., 2009. 716 p.).

5. Brennan G., Buchanan J. M. The power to tax: Analytic foundations of a fiscal constitution. Cambridge, Cambridge University Press, 1980. 231 p.

\section{Baikal Research Journal}


6. Ermakova Ye. A. Challenges and Opportunities Of Increasing Local Budget Revenues: Taxation Aspects. Nauka i obshchestvo = Science and Society, 2012, no. 4, pp. 27-31. (In Russian).

7. Kireyenko A. P., Orlova Y. N. Regional Fiscal Policy in the Context of Russian Fiscal Federalism. Region: ekonomika $i$ sotsiologiya = Region: Economics and Sociology, 2014, no. 1 (81), pp. 193-217. (In Russian).

8. Kireenko A. P., Sorokina T. V. Taxation In Inter-Budgetary Relations. Baikal Research Journal, 2011, no. 5, pp. 2. Available at: http://brj-bguep.ru/reader/article.aspx?id=9671. (In Russian).

9. Pinskaya M. R. Land Taxation and Reserves of Local Budgets Tax Income Growth. Nalogi $i$ finansy $=$ Taxes and Finances, 2014, no. 2. pp. 26-32. (In Russian).

10. Istomina N. A. Regional practice of establishing differentiated norms of deductions for taxes for budgets of municipalities. Izvestiya Ural'skogo gosudarstvennogo ekonomicheskogo universitetata = Journal of the Ural State University of Economics, 2011, no. 6 (38), pp. 28-40. (In Russian).

11. Kolodina E. A. Fiscal Federalism as Basis for Regional Economic Policy in Modern Russia. Izvestiya Irkutskoi gosudarstvennoi ekonomicheskoi akademii = Izvestiya of Irkutsk State Economics Academy, 2011, no. 6. pp. 121-124. (In Russian).

12. Pokrovskaya N. V. Role Of Tax Transfers In Forming Local Budgets In Russian Federation. Baikal Research Journal, 2015, vol. 6, no. 3, pp. 8. DOI: 10.17150/2072-0904.2015.6(3).8. Available at: http://brj-bguep.ru/reader/article.aspx?id=20121. (In Russian).

13. Sumskaya T. V. Key Way to Have More Consolidated Local Budgets. Region: ekonomi ka $i$ sotsiologiya = Region: Economics and Sociology, 2010, no. 1. pp. 235-254. (In Russian).

14. Ivanova O. Yu., Polyakova O. Yu. Tax aspects of financial resources decentralization. Journal of Tax Reform, 2016, vol. 2, no. 1, pp. 25-42. DOI: 10.15826/jtr.2016.2.1.015.

15. Khon S. S., Maiburov I. A. Systematic approach to real estate taxation of organizations. Innovatsionnoe razvitie ekonomiki = Innovative development of economy, 2016, no. 3-1 (33), pp. 253-258. (In Russian).

\section{Информация об авторах}

Киреенко Анна Павловна - доктор экономических наук, профессор, зав. кафедрой налогов и таможенного дела, Байкальский государственный университет, 664003, г. Иркутск, ул. Ленина, 11, e-mail: KireenkoAP@bgu.ru.

Орлова Елена Николаевна - кандидат экономических наук, доцент, Байкальский государственный университет, 664003, г. Иркутск, ул. Ленина, 11, e-mail: OrlovaEN@bgu.ru.

\section{Authors}

Anna P. Kireyenko - Doctor habil. in Economics, Professor, Head of Chair of Taxes and Customs, Baikal State University, 664003, Irkutsk, 11 Lenin St.; e-mail: kireenkoAP@bgu.ru.

Yelena N. Orlova - PhD in Economics, Baikal State University, 664003, Irkutsk, 11 Lenin St.; e-mail: orlovaEN@bgu.ru.

\section{Для цитирования}

Киреенко А. П. Повышение доходного потенциала местных бюджетов на основе закрепления дополнительных налоговых доходов / А. П. Киреенко, Е. Н. Орлова // Baikal Research Journal. — 2017. - T. 8, № 4. - DOI : 10.17150/2411-6262.2017.8(4).14.

\section{For Citation}

Kireyenko A. P., Orlova Ye. N. Increasing the Revenue Potential of the Local Budgets Through the Attachment of Additional Tax Revenues. Baikal Research Journal, 2017, vol. 8, no. 4. DOI: 10.17150/2411-6262.2017.8(4).14. (In Russian).

\section{Baikal Research Journal}

